in the serum, ${ }^{24}$ but less susceptible pneumococci may not be eradicated despite lung tissue concentrations exceeding those in serum. ${ }^{25}$

Even if permanently eradicating infection from patients with advanced chronic suppurative lung disease remains a forlorn hope, better recognition of the behaviour of antibiotics in the respiratory tract should help in assessing new therapeutic regimens.

JANE SYMONDS

Consultant Microbiologist,

Russells Hall Hospital,

Dudley DY1 2HQ

1 Hallstrom $\mathrm{O}$, Keyrilainen $\mathrm{O}$, Markhula $\mathrm{H}$. Ampicillin concentration in normal and pathological lung tissues after oral administration of bacampicillin. Infection 1979;7(suppl 5):469-71.

2 Stewart SM, Fisher M, Young JE, Lutz W. Ampicillin levels in sputum, serum and saliva. Thorax 1970;25:304-11.

3 Stewart SM, Anderson IME, Jones GR, Calder MA. Amoxycillin levels in sputum, serum and saliva. Thorax 1974;29:110-4.

4 Ingold A. Sputum and serum levels of amoxycillin in chronic bronchial infections. $\mathrm{Br} \mathcal{F}$ Dis Chest 1975;69:211-6.

5 Davies B, Maesen F. Serum and sputum antibiotic levels after ampicillin, amoxycillin and bacampicillin in chronic bronchitis patients. Infection 1979;7(suppl 5):465-71.

6 Cole PJ, Roberts DE, Davies SF, Knight RK. A simple oral antimicrobial regimen effective in severe chronic bronchial suppuration associated with culturable Haemophilus influenzae. f Antimicrob Chemother 1983;11:109-13.

7 Maesen FPV, Beeuwkes H, Davies BI, et al. Bacampicillin in acute exacerbations of chronic bronchitis-a dose range study. I Antimicrob Chemother 1976;2:279-85.

8 Saggers BA, Lawson D. In vivo penetration of antibiotics into sputum in cystic fibrosis. Arch Dis Child 1968;43:404-9.

9 Marlin GE, Burgess KR, Burgoyne J, Funnell GR, Guinness MDG. Penetration of piperacillin to bronchial mucosa and sputum. Thorax 1981;36:774-80.

10 Smith BR, LeFrock JL. Bronchial tree penetration of antibiotics. Chest 1983;6:904-8.

11 Lode H, Gruhlke G, Hallermann W, Dzwillo G. Significance of pleural and sputum concentrations for antibiotic therapy of bronchopulmonary infections. Infection 1980;8(suppl 1):49-53.

12 Halprin GM, McMahon SM. Cephalexin concentrations in sputum during acute respiratory infections. Antimicrob Agerts Chemother 1973;3:703-7.

13 Bergogne-Berezin E. Antibiotics in the respiratory tree. $f$ Antimicrob Chemother 1981;8:171-4.

14 Naeverson MA. Intravenous administration of erythromycin: serum, sputum and urine levels. Curr Med Res Opin 1976;4:359-64.

15 Marlin GE, Davies PR, Rutland J, Berend N. Plasma and sputum erythromycin concentrations in chronic bronchitis. Thorax 1980;35:441-5.

16 Seigler D, Kaye CM, Reilley S, Willis AT, Sankey MG. Serum, saliva and sputum levels of metronidazole in acute exacerbations of chronic bronchitis. Thorax 1981;36:781-3.

17 MacCulloch D, Richardson RA, Allwood GK. The penetration of doxycycline, oxytetracycline and minocycline into sputum. N Z Med f 1974;80:300-2.

18 Maesen FPV, Davies BI, Van Noord JA. Doxycycline in respiratory infections: a re-assessment

after 17 years. I Antimicrob Chemother 1986;18:531-6.
19 Gartmann J. Doxycycline concentrations in lung tissue, bronchial wall and bronchial secretion. Chemotherapy 1975;21:19-26.

20 Noone P, Parsons TMC, Pattison JR, et al. Experience in monitoring gentamicin therapy during treatment of serious Gram-negative sepsis. Br Med F 1974;i:477-81.

21 Pennington JE, Reynolds HY. Concentrations of gentamicin and carbenicillin in bronchial secretions. F Infect Dis 1973;128:63-8.

22 Hughes DTD. The use of combinations of trimethoprim and sulphonamides in the treatment of chest infections. I Antimicrob Chemother 1983;12:423-34.

23 Brumfitt W, Hamilton-Miller JMT, Howard CW, Tansley H. Trimethoprim alone compared to co-trimoxazole in lower respiratory infections: pharmacokinetics and clinical effectiveness. Scand I Infect Dis 1985;17:99-105.

24 Bergogrie-Berezin E, Berthelot G, Even P, Stern M, Reynaud P. Penetration of ciprofloxacin into bronchial secretions. Eur 7 Clin Microbiol 1986;5:197-200.

25 Schlenkhoff D, Knopf J, Dalhhoff A. Penetration of ciprofloxacin into human lung tissue. In: Neu HC, Weuta H, eds. Proceedings of The Ist International ciprofloxacin workshop. Amsterdam: Neu HC, Weuta H, eds. Proceedings of The Ist Intermational ciprofloxacin
Excerpta Medica, 1985:157-9. (Current Clinical Practice Series No 34).

\section{Evaluating mass training in cardiopulmonary resuscitation}

The Save a Life campaign, which was started in October 1986 to stimulate mass training in emergency first aid, rightly emphasised cardiopulmonary resuscitation-the most complex first aid skill. Such campaigns are not new, and the teaching of rescue breathing has been compulsory in Norwegian schools since the early 1960 s. ${ }^{1}$ Recommendations have been made for including training on resuscitation in schools, ${ }^{2}$ and there is advice on organising community or mass training. ${ }^{3-7}$ But do the benefits of these schemes justify the costs or could the resources be better used?

Many researchers have explored the benefits for real casualties of bystanders being trained in cardiopulmonary resuscitation, ${ }^{8-14}$ and empirical calculations suggest that a trained bystander can improve the survival chance of somebody with ventricular fibrillation from $21 \%$ to $43 \%$. ${ }^{15} \mathrm{Up}$ to two lives for every 10000 . people could thus be saved annually. ${ }^{16-18}$ Such calculations also suggest that a trained lay person will meet a casualty between once in 25 years to once in over 112 years. ${ }^{16-20}$

Some of these uncertainties have been incorporated into a $\mathbb{D}$ model of the cost effectiveness of training programmes in cardiopulmonary resuscitation. ${ }^{21}$ Important questions are how often people should be retrained, whether resources should be concentrated on training key groups, and what sort of people should be trained. Over 40 studies have shown that the skills of cardiopulmonary resuscitation decay rapidly. ${ }^{1922}{ }^{23}$ Research is equivocal whether training should be concentrated in medical and paramedical groups. ${ }^{2427}$

A survey of over 3000 people showed individual differences in willingness to attempt cardiopulmonary resuscitation, but over $40 \%$ reported that they would do something. ${ }^{28}$ Reported willingness and actually carrying out cardiopulmonary resuscitation are, however, different things: when medical or paramedical people witnessed a collapse then cardiopulmonary resuscitation was performed in one third of cases, but when only non-medical people were present then resuscitation was performed in about one in every 25 cases. ${ }^{17}$ Whether people help depends on how clearly they understand what is happening and on whether other people are present. ${ }^{29}$ This study also found that women helped less often than men and that, though training did not raise the intervention rate, it did increase dramatically the effectiveness of help given.

Some have argued, however, that even when a rescuer does little or performs cardiopulmonary resuscitation inadequately the survival chances still improve. ${ }^{30}$ Others have questioned whether "retention of classroom skills is related to performance during actual resuscitation attempts or to eventual clinical outcomes."22 The dearth of empirical studies comparing "classroom skills" with actual performance means that this assertion remains untested. In studies of medical students and hospital staff it has been suggested that some may have performed better in real emergencies and some worse. ${ }^{31} 32$

Many cases are required to determine the effectiveness of interventions. Assessment is complicated by the nature of the incident that causes breathing to fail and the heart to stop. In some cases cardiopulmonary resuscitation would be unsuccessful however well performed, but developing and maintaining the blood pressure and circulation of oxygen for $\frac{9}{7}$ adequate tissue perfusion and continuing brain function $\mathrm{N}$ demand a high level of skill. Therefore, there is no basis for $\vec{z}$ assigning low importance to initial and refresher training in cardiopulmonary resuscitation. As rescuers will not require $\tilde{O}$ the full repertoire of skills in every incident excellent training is required for trainees to have adequate knowledge and skills from which to draw should the need arise.

Criticisms of mass training in cardiopulmonary resuscitation are that trainees develop a false sense of competence ${ }^{20}:$ and that resuscitation might be performed unnecessarily or hazardously. ${ }^{33-35}$ High drop out rates among volunteer instructors have also been encountered. ${ }^{36}$ Some of these problems would be overcome by thorough training and regular refresher training, with particular emphasis on diagnosis. Evaluation of mass training should also take account of possible hidden benefits. For example, we have shown that

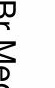


first aid training both at work and in the community is associated with a considerable improvement in accident rates. ${ }^{3738}$ Another benefit is greater appreciation among lay people of the early symptoms of heart attack and of the importance of contacting the emergency medical services early.

The costs of mass training must include those of monitoring, evaluation, follow up and refresher training. Analysis of both costs and benefits is difficult, but if mass training is to be raised from the domain of the enthusiastic amateur to that of the professional scientist the analysis must be undertaken.

\section{A IAN GLENDON} Lecturer

Organisation Studies and

Applied Psychology Division,

Aston University,

Birmingham B4 7ET

Sandwell Industrial and

First Aid Training Service,

Birmingham

STEPHEN S BLAYLOCK Training consultant

West Midlands Industrial Health Service,

Birmingham

KAREN HUNT

Training Officer

Sandwell Industrial Nursing and

First Aid Training Service,

Birmingham

Correspondence to: Dr Glendon

1 Lind B, Stovner J. Mouth-to-mouth resuscitation in Norway. JAMA 1963;185:933.

2 Britton RJ. CPR in the schools: training students to save heart attack victims. Symergist 1978;7: 9-11.

3 Mandel L, Cobb LA. Initial and long-term competency of citizens träined in CPR. Emengency Health Services Quarnerly 1982;1:49-63.

4 Fisher JM. Improving the standards and practice of cardiopulmonary resuscitation. Joumal of the British Associanion for Imediale Care 1985;8:3-5.

5 Flax $P$, Larke T, Walser G, Kaye $W$, Uhley $H$. The mechanics of widespread training of cardiopulmonary resuscitation: a community project implemented by volunteers. Am Heart $\mathcal{J}$ 1976;91:123-5.

6 Briggs RS, Brown PM, Crabb ME, a al. The Brighton resuscitation ambulances: a continuing experiment in pre-hospital care by ambulance staff. $B r$ Med $\mathcal{O} 1976$;ii:1161-5.

7 Vincent R, Martin B, Williams G, Quinn E, Robertson G, Chamberlain DA. A community training scheme in cardiopulmonary resuscitation. Br Med J 1984;288:617-20.

8 Copely DP, Mantle JA, Rogers WT, Russel RO, Rackley CE. Improved outcome for pre-hospital cardiopulmonary collapse with resuscitation by bystanders. Circulation 1977;56:901-5.

9 Lund I, Skulberg A. Cardiopulmonary resuscitation by lay people. Lancet 1976;ii:702-4.

10 Tweed WA, Brustow G, Donen N. Resuscitation from cardiac arrest: assessment of a system providing only basic life support outside of hospital. Can Med Assoc f 1980;122:297-300.

1 Cummins RO, Eisenberg MS. Prehospital cardiopulmonary resuscitation: is it effective? $\mathcal{J} A M A$ 1985:253:2408-12.

12 Cummins RO, Eisenberg MS, Hallstrom AP, Litwin PE. Survival of out-of-hospital cardiac arrest with early initiation of cardiopulmonary resuscitation. Am $\mathcal{F}$ Emerg Med 1985;3:114-8.

13 Ritter G, Wolfe RA, Goldstein S, et al. The effect of bystander CPR on survival of out-of-hospital cardiac arrest victims. Am Hean $\mathcal{Y}$ 1985;110:932-7.

14 Stueven $H$, Troiano $P$, Thompson B, et al. Bystander/first responder CPR: ten years experience in a paramedic system. Ann Emerg Med 1986;15:707-10.

15 Thompson RG, Hallstrom AP, Cobb LA. Bystander-initiated cardiopulmonary resuscitation in the management of ventricular fibrillation. Ann Intem Med 1979;90:737-40.

16 Eisenberg MS, Bergner L, Hallstrom A. Epidemiology of cardiac arrest and resuscitation in a suburban community. Fournal of the American College of Emergency Physicians 1979;8:2-5.

17 Crampton RS, Aldrich RF, Gascho JA, Miles JR, Stillerman R. Reduction of prehospital, ambulance and community death rates by the community-wide emergency cardiac care system. Am $\mathcal{F}$ Med 1975;58:151-65.

18 Hart HN, Slooff R. Resusciation by lay bystanders: are we heading in the right direction? foumal of the World Association for Emergency and Disaster Medicine 1986;1-4:167-70.

19 Glendon AI, Blaylock SS, McKenna SP, Hunt K. Cardiopulmonary resuscitation skill decay: current research and findings. British Health and Safeyy Society Newsletter 1986;13:14-18.

20 Thrasher MR, Thrasher CL. Heart disease awareness and intervention training: an alternative to citizen CPR. Fournal of the World Association for Emergency and Disaster Medicine 1986;1-4: 181-6.

21 Gorry GA, Scott DW. Cost-effectiveness of cardiopulmonary resuscitation training programs. Health Sero Res 1977;12:30-41.

22 Kaye W, Mancini ME, Rallis SF, et al. Can better basic and advanced cardiac life support improve outcome from cardiac arrest? Crit Cane Med 1985;13:916-20.

23 McKenna SP, Glendon AI. Occupational first aid training: decay in cardiopulmonary resuscitation (CPR) skills. Fournal of Occupational Psychology 1985;58:109-17.

24 Sampson P. Laymen may outscore physicians in cardiopulmonary resuscitation. JAMA 1978;239:391-2.

25 McManus WF, Darin JC. Can the well trained EMT-paramedic maintain skills and knowledge? foumal of the American College of Emergency Physicians 1976;5:984-6.

26 Czaja SJ, Drury CG. A regional evaluation of EMT training. Emergency Medical Services 1979;7:77-121.

27 Frazier WH, Cannon JF. Emergency medical technicians performance evaluation. Washington DC: National Centre for Health Services Research, 1978. (Research Report Series, US Department of Health, Education and Welfare, Public Health Service No 78-3211.)
28 Mayer EL, Airola S. Bystanders_can they handle the pressure? Joumal of the Emergency Medical Services 1983;9:32-4.

29 Shotland RL, Heinold WD. Bystander response to arterial bleeding: helping skills, the decisionmaking process and differentiating the helping response. $\mathcal{J}$ Pers Soc Psychol 1985;49:347-56.

30 Cummins RO, Eisenberg MS. Cardiopulmonary resuscitation-American style. Br Med $\mathrm{J}$ 1985;291:1401-3.

31 Nelson M. Evaluation of CPR performance among medical students, residents and attendings at Mount Sinai School of Medicine. Mt Sinai 7 Med (NY) 1981;48:89-94.

32 Nelson M, Brown CG. CPR instruction: modular versus lecture course. Ann Emerg Med 1984;13:118-21.

33 Messert B, Quaglieri C. Cardiopulmonary resuscitation, perspectives and problems. Lancet 1976;ii:410-2.

34 Gombeski WR, Effron DM, Ramirez Á, Moore TJ. Impact on retention: comparisons of two CPR programmes. Am $\mathcal{Y}$ Public Health 1982;72:849-52.

35 Kaye W, Mancini ME Retention of cardiopulmonary resuscitation skills by physicians, registered nurses, and the general public. Crit Care Med 1986;14:620-2.

36 Mills A, Wilson E, Tweed WA. Heart alert: Evaluation of a community training program for cardiopulmonary resuscitation. Can Med Assoc F 1981;124:1135-9.

37 McKenna SP, Hale AR. The effect of emergency first aid training on the incidence of accidents in factories. Fournal of Occupational Accidents 1981;3:101-14.

38 Glendon AI, McKenna SP. Using accident injury data to assess the impact of community first aid raining. Public Health 1985;99:98-109.

\section{Causes of blindness in schoolchildren}

In the early part of the nineteenth century two thirds of the inmates of the Liverpool School for the Indigent Blind had lost their sight as a result of smallpox. Towards the end of the century ophthalmia neonatorum had become the leading cause of blindness in schoolchildren, accounting for about a third of cases. Today genetic disease has become the major cause of blindness in schoolchildren.

Much of our knowledge of the causes of blindness in Britain comes from the monographs published between 1950 and 1979.14 In the most recent of these ${ }^{4}$ optic atrophy, congenital anomalies, and cataracts accounted for nearly $60 \%$ of all new blind and partially sighted registrations in patients up to 15 years of age. Studies in schools for the visually handicapped showed that in Britain in the early 1960s the three commonest causes of blindness (accounting for over half the cases) were retinopathy of prematurity, chorioretinal degenerations (retinitis pigmentosa, Leber's amaurosis, and related conditions), and cataract..$^{5}$ About half the disorders were genetically determined, $20 \%$ of all cases being autosomal dominant, $17 \%$ autosomal recessive, and $5 \%$ $\mathrm{X}$ linked; $8 \%$ were thought to be multifactorial. In a European study a decade later there was a remarkable similarity between the findings in the Netherlands, Belgium, Norway, and Denmark. ${ }^{6}$ One half of the cases were equally divided between tapetoretinal dystrophies (retinitis pigmentosa group, including the macular dystrophies), optic atrophy, and cataract, and the addition of congenital malformations and retinopathy of prematurity brought the total to $74 \%$. Again, in the most recent of these studies, on 99 children in the Royal Blind School, Edinburgh, almost half were genetically determined.?

Blindness in children resulting from genetically determined diseases imposes a heavy social, health, and educational burden on the community. There are two methods of reducing the birth frequency of monogenetically determined diseases: primary prevention by genetic counselling, and secondary prevention by recognising affected fetuses and abortion. ${ }^{8}$

In addition to primary prevention genetic counselling has a further valuable role: it reassures those not at risk of transmitting the disorder. Counselling should be offered to all visually handicapped teenagers, preferably in their last 